\title{
Особливості мануальної терапії у пацієнтів із синдромом хребтової артерії
}

\author{
УДК 619:616-005.2:615.825
}

\section{Г. Б. Лабінська}

Львівський національний університет ветеринарної медицини та біотехнологій імені С. З. Ґжицького, Львів, Україна

\begin{abstract}
Резюме. Нині головними чинниками виникнення в осіб молодого віку порушень мозкового кровотоку є зміни в шийному відділі хребта. Мета. Проаналізувати ефективність мануальної терапії у студентів із синдромом функціональної компресії хребтової артерії внаслідок порушення біомеханіки в шийному відділі хребта. Методи. Теоретичний аналіз і узагальнення літературних джерел, опитування, комплексне ультразвукове дослідження, методи математичної статистики. Результати. Заняття за розробленою програмою, що включали лікувальну гімнастику, постізометричну релаксацію м'язів і м'які техніки мобілізації для розблокування функціональних блоків у міжхребцевих рухомих сегментах шийного відділу хребта, показали значне покращення клінічного стану обстежуваних. Результати дослідження показали, що застосування запропонованої комплексної програми, яка включає мануальну терапію, сприяє зниженню клінічних проявів захворювання і в короткі строки повертає пацієнтам якість життя. Ключові слова: синдром хребтової артерії, мануальна терапія, фізична терапія.
\end{abstract}

Peculiarities of manual therapy in patients with the vertebral artery syndrome

\section{H. B. Labinska}

Lviv National University of Veterinary Medicine and Biotechnology named after S.Z. Gzhytsky, Lviv, Ukraine

Abstract. Currently, the main factors in the occurrence of cerebral blood flow impairments in young people are changes in the cervical spine. Objective. To analyze the effectiveness of manual therapy in students with the syndrome of functional compression of the spinal artery due to a violation of biomechanics in the cervical spine. Methods. Theoretical analysis and generalization of literature sources, surveys, complex ultrasound investigation, methods of mathematical statistics. Results. Classes according to the developed program, which included therapeutic gymnastics, postisometric muscle relaxation and soft mobilization techniques to unlock functional blocks in the intervertebral motor segments of the cervical spine, showed a significant improvement in the clinical condition of the subjects. The results of the study indicated that the use of the proposed complex program, which includes manual therapy, reduces the clinical manifestations of the disease and in a short time restores patients' quality of life.

Keywords: spinal artery syndrome, manual therapy, physical therapy.

Постановка проблеми. Значне поширення цереброваскулярних захворювань, які $€$ однією з основних причин смертності і стійкої інвалідизації, на сьогодні становлять актуальну проблему судинної патології головного мозку. За різними даними, частота дисгемій у вертебробазилярному басейні (ВББ) становить 25-30 \% усіх порушень мозкового кровообігу, в тому числі до $70 \%$ транзиторних ішемічних атак $[11,13]$.

Головним етіопатогенетичним фрактором розвитку порушень кровотоку у ВББ є зміни шийного відділу хребта, що в останні роки стали значно поширеними у людей молодого віку. Згинання шийного відділу хребта під час тривалої роботи за комп'ютерами, планшетами та смартфонами чинить на нього механічне навантаження та призводить до ряду порушень біомеханіки хребта. У сучасній медичній літературі воно отримало назву «text-neck» [12]. Студенти тривалий час працюють у вимушеному положенні голови та тіла, внаслідок чого у них розвиваються ізометричне напруження м'язів шиї, міофрасціальні гіпертонуси, які 
ведуть до появи фуннціональних блоків хребцеворухових сегментів та виникнення фрункціональних біомеханічних змін, що проявляються синдромом фрункціональної компресії хребтової артерії [8]. Ресрлекторне звуження, компресія хребтових артерій, їх деформація проявляються синдромом хребтової артерії, який включає комплекс церебральних, судинних та вегетативних синдромів.

Основним патогенетичним механізмом синдрому хребтової артерії $€$ компресія стовбура артерії, вегетативного сплетіння і звуження просвіту судини у зв'язку з ресрлекторним спазмом, що веде до зниження притоку крові до задніх відділів мозку з наступним розвитком недостатності мозкового кровообігу. Розвиток вертебрально-базилярної недостатності в осіб молодого віку, що виникає на тлі патобіомеханічних змін шийного відділу хребта, неминуче впливає на якість життя, яка, за визначенням В003, є інтегральною характеристикою фрізичного, психологічного, емоційного і соціального функціонування хворого, заснованою на його суб'єктивному сприйнятті [3-5, 7].

Медикаментозне лікування синдрому компресії хребтової артерії дає неповний та короткочасний ефект [10]. У сучасній літературі існує недостатньо досліджень, в яких наводяться дані про ефрективність застосування засобів фрізичної терапії синдрому хребтової артерії [6]. Зокрема, вельми цікавими є дослідження лікування цього синдрому методом мануальної терапії [9], оскільки він $€$ ефективним, економічно вигідним та дозволяє у короткі строки повернути пацієнту якість життя. Тому пошук нових засобів і методів фрізичної терапії хворих із синдромом хребетової артерії та оцінювання їх ефективності $€$ важливою та актуальною медико-соціальною проблемою.

Роботу виконано в межах науково-дослідної роботи кафедри реабілітації та здоров'я людини Львівського національного університету ветеринарної медицини та біотехнологій імені С. 3. Гжицького на тему «Особливості фрізичної терапії захворювань екстрапірамідної нервової системи та церебральних транзиторних ішемічних нападів і супутніх синдромів» (номер держреєстрації 0120U100690).

Мета дослідження - провести аналіз ефективності мануальної терапії у студентів із синдромом фрункціональної компресії хребтової артерії внаслідок порушення біомеханіки в шийному відділі хребта.

Методи дослідження: теоретичний аналіз і узагальнення науково-методичної літератури, опитування, ультразвукове дослідження, методи математичної статистики.
Результати дослідження та їх обговорення. Було обстежено 24 студенти 18-23 років із синдромом функціональної компресії хребтової артерії до та після застосування курсу мануальної терапії. Від усіх обстежуваних було отримано інорормовану згоду на проведення фрізичної терапії, зокрема мануальної терапії. Дослідження проводили на клінічних базах університету.

У всіх обстежуваних було виявлено біомеханічні порушення в шийному відділі хребта у вигляді обмеження обсягу активних та/або пасивних рухів у шийному відділі хребта, ознаки нестабільності хребтових рухових сегментів.

Оцінювання вегетативного статусу проведено до та після лікування. Клінічне оцінювання вегетативних порушень разом із неврологічним та загальноклінічним оглядом включало «Опитувальник для визначення ознак вегетативних змін» О. М. Вейна (заповнювався студентами самостійно). Сума балів, що перевищувала 15, свідчила про наявність вегетативної дисорункції.

Провідними були скарги на головний біль, що локалізувався в шийно-потиличній ділянці і поширювався вперед та посилювався під час рухів голови, біль у ділянці шиї, що іррадіював у надпліччя, руку, відчуття «туману» та появу «мушок» перед очима під час нападу головного болю, запаморочення. Крім цього, студенти скаржилися на серцебиття, швидку втомлюваність, зниження працездатності, сонливість.

Усім обстежуваним проводили комплексне ультразвукове дослідження судин (КУЗД) голови та шиї, яке включало стандартне ультразвукове дослідження та дуплексне сканування цих судин із застосуванням фуннціональних проб з ротацією голови. У ході обстеження було виключено пацієнтів з органічною компресійною формою синдрому хребтової артерії.

Дуплексне сканування судин проводили за стандартною методикою із застосуванням функціональних проб з ротацією голови до та після застосування комплексної програми фрізичної терапії. Було проведено оцінювання швидкісних параметрів кровотоку, а саме пікової систолічної, та середньої швидкості кровотоку, периферійного судинного опору. Також проводили фрункціональні тести, які включали нахили голови вперед, назад; повертання голови вправо, вліво.

Програма фрізичної терапії включала лікувальну гімнастику, лікувальну фрізкультуру (ЛФК), постізометричну релаксацію м'язів і м'які техніки мобілізації для розблокування функціональних блоків у міжхребцевих рухомих сегментах шийного відділу хребта. ЛФК проводили тричі на тиждень у вигляді симетричних, несиметричних та 
дисторсійних вправ, розроблених індивідуально для кожного студента, враховуючи особливості його постави та, відповідно, біомеханіки хребта. Сеанси зазвичай тривали до 30 хв і включали також вправи на зміцнення м'язів шиї, трапецієподібних м'язів у положенні сидячи, стоячи і лежачи $з$ поступовим їх напруженням. Лікувальну гімнастику призначали після зменшення гострого болю. Обертальні рухи в шийному відділі хребта, а також закидання голови з перерозгинанням хребта проводили дуже обережно під контролем напруженості м'язів для уникнення можливого розвитку гіпермобільності хребців. Курс фрізичної терапії тривав 4 тижні.

Перед сеансом мануальної терапії проводили короткий сеанс масажу шиї та комірцевої зони для прогрівання паравертебральних м'язів і зменшення м'язового спазму. Особливостями мануальної терапії було те, що використовували м'якотканинні методики, а саме міофасціальне розслаблення, постізометричну релаксацію м'язів, краніосакральні техніки. Постізометрична релаксація м'язів, на відміну від маніпуляції, завдяки своєму м'якому, щадному впливу дозволена до використання при синдромі компресії хребтової артерії. Всього на курс лікування було проведено в середньому по п'ять процедур мануальної терапії.

В обстежуваних до проведення фрізичної терапії, за даними ультразвукового дослідження, спостерігали незначне зниження показників гемодинаміки по хребтових артеріях. Також під час проведення фрункціональних проб спостерігали зменшення швидкості кровотоку під час повертання голови $з$ наступним ії збільшенням при зміні положення голови.

Результати анкетування пацієнтів за даними «Опитувальника для визначення ознак вегетатив- них змін» О. М. Вейна показали значні зміни у вихідному вегетативному статусі (табл. 1). Зокрема, найбільш поширеними клінічними ознаками були напади головного болю (96 \%), зниження працездатності та втомлюваність (91\%), порушення сну (88 \%), серцебиття (78 \%), відчуття затруднення дихання, нестачі повітря $(70 \%)$ тощо. Після проведеного курсу фрізичної терапії було повторно оцінено вегетативний статус (див. табл. 1). Як видно з таблиці, значно зменшилася кількість хворих, які виявляли певні скарги до проведеного курсу фізичної терапії.

Після проведеного курсу комплексної фрізичної терапії було здійснено повторне ультразвукове обстеження, за даними якого виявлено покращення гемодинаміки в хребтових артеріях.

Після опрацювання даних анкет було проведено їх статистичну обробку та отримано такі результати: середнє значення балів до проведення курсу фрізичної терапії становило 39,435 \pm $8,938$ ( $= \pm 1,864)$, а після проведеного курсу $6,913 \pm 4,055$ (м = $\pm 0,846$ ), коефіцієнт Стьюдента $(\mathrm{t})$ становив 2,074, a $\mathrm{p} \leq 0,05$, що свідчить про статистичну достовірність результатів.

Таких результатів було досягнуто, ймовірно, завдяки нормалізації анатомо-функціональних взаємозв'язків у шийному відділі хребта, стимуляції його репаративних можливостей за допомогою мануальної терапії $[14,15]$. Патологічні зміни при порушенні біомеханіки шийного відділу хребта можна розглядати на трьох рівнях: перифреричному (м'які тканини), нейрофрізіологічному та психофрізіологічному.

Мануальна терапія на рівні м'яких тканин виконує такі завдання: пришвидшує репаративні процеси, відновлює фрізичні і механічні характеристики тканинних структур, у тому числі спаз-

ТАБЛИЦЯ 1 - Вегетативний статус за «Опитувальником для визначення ознак вегетативних змін» О. М. Вейна до та після курсу фізичної терапії

\begin{tabular}{|l|c|c|c|c|}
\hline \multirow{2}{*}{ Ознаки } & \multicolumn{2}{|c|}{$\begin{array}{c}\text { До проведення } \\
\text { курсу }\end{array}$} & \multicolumn{2}{c|}{ Після проведення курсу } \\
\cline { 2 - 5 } & $\mathbf{n}$ & $\%$ & \multicolumn{2}{c|}{$\mathbf{n}$} \\
\hline Схильність до почервоніння або побіління обличчя & 14 & 61 & 6 & 26 \\
\hline Оніміння або охолонення пальців & 15 & 65 & 6 & 26 \\
\hline Зміна кольору пальців & 8 & 33 & 3 & 13 \\
\hline Відчуття серцебиття, зупинки серця & 18 & 78 & 2 & 9 \\
\hline Підвищена пітливість & 8 & 35 & 1 & 4 \\
\hline Відчуття затруднення дихання, нестачі повітря & 16 & 70 & 5 & 22 \\
\hline Знепритомнення в душному приміщенні, при хвилюванні & 5 & 22 & 0 & 0 \\
\hline $\begin{array}{l}\text { Порушення функцій травної системи (схильність до запорів, } \\
\text { проносів, здуття живота) }\end{array}$ & 8 & 35 & 1 & 4 \\
\hline Напади головного болю & 22 & 96 & 5 & 22 \\
\hline Зниження працездатності та втомлюваність & 21 & 91 & 6 & 26 \\
\hline Порушення сну & 20 & 88 & 3 & 13 \\
\hline
\end{tabular}


мованих чи перерозтягнутих тканин, а також нормалізує циркуляцію фрізіологічних рідин у тканинах. Вона впливає також на пропріоцептивні механізми, стимулюючи різні групи механорецепторів у зоні ураження і навколо неї. Одним 3 основних нейрофрізіологічних ефектів мануальної терапії $€$ гіпоаналгезія, що розвивається в перші секунди після маніпуляції. Мануальна терапія викликає психосоматичну та психофрізіологічну відповідь усього організму, що проявляється зміною м'язового тонусу, зростання толерантності до болю, покращення процесів саморегуляції [2].

\section{Література}

1. Бишевець Н. Удосконалення контролю робочої пози студента за комп'ютером у освітньому процесі [Improving the control of the student's working posture at the computer in the educational process]. Сучасні біомеханічні та інформаційні технології у фізичному вихованні і спорті: матеріали конференції. Київ. 2019: 57-59.

2. Забаровский ВК. Механизмы действия мануальной терапии [Manual therapy mechanisms of action]. Медицинские новости. 2007; 1: 7-12.

3. Кашуба В, Попадюха Ю. Біомеханіка просторової організації тіла людини: сучасні методи та засоби діагностики і відновлення порушень [Biomechanics of spatial organization of the human body: modern methods and tools for diagnosing and repairing disorders]: монографрія. Київ: Центр учб. літ., 2018. 768 c.

4. Кашуба ВА, Бондарь ЕМ, Гончарова НН, Носова НЛ. Формирование моторики человека в процессе онтогенеза: монографрія [Formation of human motor skills in the process of ointogenesis]. Луцьк: Вежа-Друк. 2016. $232 \mathrm{c}$.

5. Кашуба В, Альошина А, Бичук О, Лазько О, Хабінець Т, Руденко Ю. Характеристика мікроергономіки системи «людина-комп'ютер» як передумова розробки корекційно-профілактичних заходів із використанням вправ різної біомеханічної спрямованості [Characteristics of human-computer microergonomics as a prerequisite for the development of corrective and preventive measures using exercises of different biomechanical orientation]. Молодіжний науковий вісник Східноєвропейського національного університету імені Лесі Українки. Фізичне виховання і спорт. 2017; (28): 17-27.

6. Лазарєва О, Куропятник В, Кабінський О. Особливості фізичної реабілітації осіб зрілого віку з синдромом хребетної артерії // [Features of physical rehabilitation of adults with vertebral artery syndrome]. Теорія і методика фізичного виховання і спорту. 2015; 1: 45-50.

7. Морозова О, Ярошевський О, Логвіненко Г. Динаміка якості життя у молодих пацієнтів з вертебрально-базилярною недостатністю і патобіомеханічними змінами опорно-рухового апарату на тлі комплексної немедикаментозної терапії [Dynamics of quality of life of young patients
Впливаючи на шийний відділ хребта, зокрема i методами мануальної терапії, можна боротися з основною причиною розвитку і прогресування порушень кровотоку у ВББ.

Висновки. Узагальнення науково-методичної інфрормації свідчить про поширеність синдрому компресії хребтової артерії серед осіб молодого віку. Використання мануальної терапії у програмі комплексної фрізичної терапії при синдромі хребтової артерії дозволяє значно знизити клінічні прояви захворювання і в короткі строки повернути пацієнтам якість життя.

with vertebrobasilar insufficiency and pathobiomechanical changes of the locomotorium on the background of complex non-drug therapy]. Психіатрія, неврологія та медична психологія. 2019. 10: 24-30.

8. Некрасова НО. Діагностика вертебро-базилярної недостатності у осіб молодого віку: принципи та досвід клініко-інструментальної верифрікації її спондилогенного походження Ярошевський О, Логвіненко Г. Актуальні проблеми сучасної медицини: Вісник Української медичної стоматологічної академії [Diagnosis of vertebro-basilar insufficiency in young people: principles and experience of clinical and instrumental verification of its spondylogenic origin]. 2018; 18, 2 (62):84-89.

9. Франк С, Франк М, Франк Г. Лечение синдрома позвоночной артерии методом мануальной терапии [Treatment of vertebral artery syndrome with manual therapy]. World science. 2019; 9(49): 20-27.

10. Чотчаева A, Сулейманова МА. Синдром позвоночной артерии вопросы классификации, диагностики, лечения (литературный обзор) [Vertebral artery syndrome, issues of classification, diagnosis, treatment (literature review)]. Международный студенческий научный вестник. 2016; 4-1: $91-94$.

11. Шейко НІ, Фекета ВП. Можливості використання стандартизованого опитувальника для визначення автономних дисфункцій в осіб молодого віку [Possibilities of using a standardized questionnaire to determine autonomic dysfunctions in young people] / Шейко НI, Фекета ВП. Здобутки клінічної і експериментальної медицини. 2019; 2: 170-174.

12. Barrett JM, McKinnon C, Callaghan JP. Cervical spine joint loading with neck flexion. Ergonomics. 2020 Jan;63(1):101-108.

13. Fenestrations of the intracranial vertebrobasilar system diagnosed by MR angiography / A. Uchino, N. Saito, Y. Okada [et al.]. Neuroradiology. 2012; 54(5): 445-50.

14. Lewit K. Manipulative Therapy in Rehabilitation of the Locomotor System. London: Butterworths, 1999.

15. Weldon SM, Hill RH. Manual Therapy. 2003; 8: 141-150. 